\title{
FUNDAMENTALISME HAK ASASI MANUSIA
}

Mesakh Jasnin

\section{BAB I}

\section{Latar Belakang}

Dewasa ini masalah Hak Asasi Manusia (HAM) menjadi isu yang hangat dibicarakan di hampir semua belahan dunia, termasuk Indonesia. Salah satu dari banyak permasalahan HAM itu adalah masalah eksekusi mati terhadap pelanggar hukum pidana berat. Eksekusi mati telah menjadi masalah yang mengundang pro dan kontra dari berbagai kalangan.

Pihak yang pro biasanya mempunyai tiga alasan mendukung eksekusi mati, yaitu alasan kriminal, penegakan hukum dan penegakan keadilan yang didasarkan pada empat Undang-Undang, yaitu KUHP, Perpu nomor 1 tahun 2002, UU nomor 31 tahun 1999 dan UU nomor 22 tahun 1997. Sedangkan pihak yang kontra terhadap eksekusi mati mempunyal alasan kemanusiaan yang didasarkan pada UUD 1945.

Hak Asasi Manusia adalah alasan yang logis untuk menolak eksekusi mati tersebut. Kasus terbaru saat penulis menulis karya ilmiah ini adalah vonis mati terhadap tiga orang yang dituduh terlibat dan bertanggung jawab dalam kasus kerusuhan Poso. Tiga orang terpidana itu adalah Dominggus Da Silva (39), Febianus Tibo (60) dan Marinus (48). Permohonan grasi kedua yang mereka ajukan dinilai kejaksaan tidak memiliki dasar. Padahal tuduhan terhadap mereka pun tidak terbukti di persidangan. ${ }^{1}$ Dengan kata lain vonis matinya pun tidak berdasar, apalagi pelaksanaan eksekusi matinya.

Pada dasarnya, sekalipun terpidana terbukti bersalah, Hak Asasi Manusia tetap menolak ekseskusi mati tersebut. Penolakan ini diistilahkan oleh penulis dengan "fundamentalisme HAM, yang mencakup bukan hanya penolakan terhadap hukuman mati tetapi juga eksekusi matinya. Hukuman mati hanya sebatas vonis mati sedangkan eksekusi mati adalah pelaksanaan vonis mati tersebut.

Berdasarkan uraian di atas, penulis akan mengkaji masalah HAM dan aplikasinya dalam menolak eksekusi mati dengan memberi judul pada karya ilmiah ini "FUNDAMENTALISME HAK ASASI MANUSIA."

\section{Rumusan Masalah}

Penulisan ini berupaya memecahkan persoalan-persoalan berikut.

1. Apakah hak asasi yang paling mendasar dari manusia?

2. Mengapa fundamentalisme Hak Asasi Manusia menolak eksekusi mati?

\section{Tujuan Penulisan}

1. Mendapatkan pemahaman yang jelas dan tegas tentang hak yang fundamental pada manusia.

2. Mencari kemungkinan implikasi dan implementasi HAM untuk menolak eksekusi mati.

\section{Tinjauan Pustaka}

Hak Asasi Manusia tidak pernah boleh dilepaskan dari Kewajiban Asasi Manusia. Hak mengimplikasikan kewajiban, sebab hak hanya menjadi hak setelah kewajiban terpenuhi. Sebaliknya, 
Seberat apa pun pelanggaran terpidana, hak hidupnya tidak boleh dicabut. Mencabut nyawa seseorang bukanlah hak manusia. Hanya Allah yang berhak mencabut nyawa seseorang.

\section{Metode Penelitian}

Untuk memperoleh semua data dalam karya ilmiah ini, maka penulis mengadakan penelitian terhadap buku-buku perpustakaan (library research), media surat kabar, internet dan lain-lain yang berhubungan dengan pokok masalah yang dibahas.

\section{Analisa Hasil}

Penelitian ini hasilnya dianalisis dengan pendekatan evaluasi reflektif-teologis, dalam arti bahwa data yang telah terhimpun dan terdeskripsikan ditunjukan kekhasannya, baik kelebihan maupun kekurangnnya, serta jika mungkin diberi pemecahan alternatif. Data disoroti dengan kategori ilmu teologi, dicari unsur-unsurnya yang fundamental dan sangat dasariah.

\section{BAB II \\ Fundamentalisme HAM Pengertian Istilah}

Menurut Kamus Besar Bahasa Indonesia, fundamentalisme adalah paham yang cenderung untuk memperjuangkan sesuatu secara radikal. ${ }^{2}$ Radikal berarti "secara mendasar" sampai kepada hal yang prinsip. ${ }^{3}$

Hak Asasi Manusia adalah hak yang dilindungi secara internasional (yaitu deklarasi PBB Declaration of Human Rights), seperti hak untuk hidup. ${ }^{4}$ Jhon Stoot mengutip apa yang dikatakan Thomas Paine bahwa "hak asasi manusia adalah hasil kejadian, bukan hasil jerih payah manusia. Bukan pula yang dianugrahkan pemerintah atau penguasa lain. Manusia telah memilikinya dari semula. la menerimanya bersama hidupnya dari tangan Penciptanya. Hak itu melekat dalam penciptaannya. Hak itu di berikan oleh Penciptanya."

Dari beberapa penjelasan di atas, penulis dapat mengkaji kembali konsep HAM dengan membaginya dalam dua pengertian sebagai berikut:

1. Pengertian secara sempit

Hak Asasi Manusia adalah teori atau paham mengenai hak yang paling dasar yang dirumuskan oleh manusia dan dilindungi secara internasional.

2. Pengertian secara luas

Hak asasi Manusia adalah hak yang diletakan dan dilekatkan oleh Sang Pencipta kepada manusia yang tanpa hak itu ia tidak dapat disebut manusia. Oleh sebab itu hak ini tidak dapat dilepaskan dari kodrat manusia dan tidak dapat dihilangkan oleh siapa pun.

Jadi, fundamentalisme HAM adalah paham yang memperjuangkan hak yang paling fundamental pada manusia yang menjadi prinsip mendasar bukan hanya karena dilindungi secara internasionai tetapi yang utama karena hak itu diletakan dan dilekatkan oleh Sang Pencipta.

Menarik di sini, bahwa sebenarnya HAM bukanlah hasil perjuangan manusia, tetapi pemberian dari Sang Pencipta. Lalu, kapan HAM menjadi sebuah paham yang harus diperjuangkan? Berikut dimensi historis HAM yang menjadi cikal bakal lahirnya perjuangan HAM.

\section{Sejarah Perkembangan HAM}

Sejarah perkembangan HAM harus dibahas dalam pengertian sempitnya, yaitu teori (paham) hak yang fundamental yang telah dirumuskan oleh manusia. Menurut ilmu pengetahuan sejarat. HAM baru tumbuh dan berkembang pada saat HAM itu diperhatikan dan diperjuangkan terhadap 
bahaya dan penindasan oleh kekuasaan yang dimiliki oleh suatu negara atau suatu organisasi masyarakat dimana terdapat unsur yang memerintah dan diperintah.

\section{Tabel Sejarah Perkembangan HAM}

$\begin{array}{lll}\text { Negara/tahun } & \text { Piagam } & \text { Latar belakang } \\ \text { Inggris/1215 } & \text { Magna Charta } & \text { Pada hakekatnya merupakan pembatasan } \\ \text { Inggris } / 1679 & \text { Habeas Copus Act } & \text { terhadap kekuasaan raja yang absolut } \\ \text { Inggris } / 1688 & \text { Bill of Right } & \end{array}$

Ketiga pernyataan tersebut pada hakeketnya merupakan pembatasan terhadap melawan mereka yang bertindak sewenang-wenang. Paham HAM saat itu (di Inggris) tidak bertumbuh pada hakikat dan eksistensi manusia. ${ }^{6}$ Jadi untuk mengkaji konsep HAM yang fundamental maka harus dilihat dari pengertian luasnya, yaitu HAM yang bertitik tolak dari eksistensi manusia yang merupakan kodratnya.

\section{Kodrat Manusia}

Kodrat adalah sifat aslinya atau sifat bawaan manusia. ${ }^{7}$ Oleh karena terbawa kodrat, setiap manusia selalu hadir dalam kebersamaan dengan sesamanya yang berbeda dengan dia (eksistensi yang koeksistensi). ${ }^{8}$ Jadi, dapat disimpulkan bahwa eksistensi yang koeksistensi adalah kodrat manusia. Kodrat ini berarti bahwa manusia harus mengakui kehadiran orang lain yang berbeda dengan dia dan berinteraksi dengan sesamanya.

\section{Fundamentalistis HAM}

Fundamentalistis HAM adalah hak asasi manusia yang bersifat mendasar atau fundamental. Pembahasan mengenai HAM yang fundamental harus bertitik tolak dari kodrat manusia, yaitu eksistensi yang koeksistensi.

Eksistensi yang koeksistensi hanya terdapat dalam dinamika kehidupan manusia. Dinamika kehidupan ini meliputi semua aspek seperti kehidupan rohani, jasmani, ekonomi, hukum, sosial dan lain sebagainya. Dalam semua aspek kehidupannya manusia berusaha merealisasikan dirinya secara penuh. Dengan merealisasikan dirinya secara penuh, manusia sedang berusaha melangsungkan kehidupannya.

Dengan demikian, HAM yang fundamental (mendasar) adalah hak untuk melangsungkan kehidupannya dengan merealisasikan dirinya secara penuh. Hak-hak lain separti hak kemerdekaan, hak milik, hak mendapatkan perlakuan yang sama didepan hukum dan lain sebagainya hanya merupakan bagian dari melangsungkan kehidupannya.

\section{Aplikasi Fundamentalisme HAM Menolak Eksekusi Mati}

\section{Pengertian istilah}

Menurut kamus besar bahasa Indonesia, eksekusi berarti putusan hakim terutama hukuman mati. ${ }^{9}$ Mati berarti menghilangkan nyawa. ${ }^{10}$ Menurut ensiklopedi Indonesia (wikipedia) hukuman mati adalah suatu hukuman atau vonis yang dijatuhkan pengadilan (atau tanpa pengadilan) sebagai bentuk hukuman terberat yang dijatuhkan atas seseorang akibat perbuatannya. ${ }^{11}$

Jadi, eksekusi mati adalah pelaksanaan hukuman mati dari pengadilan kepada seseorang sebagai hukuman terberat karena harus menghilangkan nyawanya.

Naluri terkuat dari setiap mahkluk hidup termasuk manusia adalah selalu ingin mempertahankan hidupnya. Jadi, secara normal terpidana yang dijatuhi hukuman mati tersebut 
ingin tetap hidup dan berusaha menghindari kematiannya. Sebab sudah merupakan sebuah konsensus setiap manusia, bahwa pembunuhan adalah perbuatan tidak terpuji dan tidak manusiawi, bahwa eksekusi mati pada hakikatnya sama dengan pembunuhan dan bahwa kehidupan dan kematian itu adalah hak mutlak Tuhan sendiri.

Dengan demikian, eksekusi mati pada hakikatnya sama dengan pembunuhan yang berarti bertentangan dengan hak yang fundamental pada manusia, yaitu hak untuk hidup. Mengeksekusi mati seseorang yang telah melakukan kejahatan adalah sama dengan bertindak sebagai Tuhan.

\section{Tinjauan Kritis Yuridis}

Di Indonesia, setidaknya ada empat undang-undang yang berlaku yang kini masih mencantumkan adanya eksekusi mati itu, yakni Kitab Undang-Undang Hukum Pidana (KUHP), Peraturan Pemerintah Pengganti Undang-Undang (Perpu) nomor 1 tahun 2002 mengenai Pemberantasan Tindak Pidana Terorisme, UU nomor 31 tahun 1999 mengenai Pemberantasan Tindak Pidana Korupsi, serta UU nomor 22 tahun 1997 tentang Narkotik. ${ }^{12}$ Keempat undang-undang ini mendukung pelaksanaan eksekusi mati bagi terpidana tertentu. Tetapi, Pemerintah sepertinya lupa bahwa hukuman mati sebenarnya bertentangan dengan Pancasila dan UUD 1945.

Salah satu gugatan terhadap penerapan hukuman mati dilontarkan oleh Direktur Eksekutuif Lembaga Kajian Demokrasi dan Hak Asasi, Asmara Nababan, Direktur Imparsial, Munir dan ahli hukum Dr. Gayus Lumbuun yang mengatakan:

"Dalam pasal 28 UUD 1945, ditegaskan bahwa hak untuk hidup... adalah hak asasi manusia yang tidak dapat dikurangi dalam keadaan apa pun. Pasal itu membawa implikasi hukum mendasar, bahwa Indonesia tidak lagi menyetujui hukuman mati. Artinya, semua peraturan dan produk hukum di bawah konstitusi, yang bertentangan dengan konstitusi harus segera dibenahi. Apa masih layak kita menghukum mati seseorang bila UUD sebagai sumber hukum tertinggi negara ini menegaskan bahwa hak untuk hidup tidak dapat dikurangi dalam keadaan apa pun," kata Nababan. Gayus menyayangkan keputusan Presiden yang menolak grasi terpidana mati. "ganti saja hukuman mati dengan pidana seumur hidup tanpa remisi," ujarnya. Munir setuju dengan pembenahan semua produk hukum, agar sejalan dengan semangat UUD 1945."13

Gugatan lainnya datang dari Koordinator Peneliti Imparsial (The Indonesian Human Right Monitor), Al araf yang mengatakan:

"Ada tiga alasan penolakan penerapan hukuman mati di Indonesia. Pertama, dari efektivitasnya, hukuman mati yang diharapkan memberi efek jera akan mengurangi angka kejahatan....Ilusi bahwa tujuan hukuman untuk mengurangi kejahatan harus dibuang jauh karena naik-turunnya kejahatan tidak dipengaruhi besarnya hukuman yang diberikan....Kedua, pada prinsipnya, keputusan hakim dalam memutus salah-benarnya seseorang sebenarnya bersifat relatif. Tak ada hakim yang dapat memutuskan bahwa keputusannya dalam menghukum seseorang mutlak 100 persen benar atau seratus persen salah. Dalam posisi itu, penafsiran, kesimpulan, dan keputusan hakim memiliki kecenderungan salah....Ketiga, penerapan hukuman mati bertentangan dengan ketentuan hukum hak asasi manusia (HAM) internasional...yang pada tahun 2005 telah diratifikasi Pemerintah Indonesia. Lebih dari itu, kebijakan itu jelas kontras dan bertentangan dengan semangat dalam Amandemen UUD 45 yang berusaha menjamin dan menjunjung tinggi hak untuk hidup sebagai hak yang tak dapat dikurangi dalam keadaan apa pun (non derogable right) sebagaimana ditegaskan dalam Pasal 28 Ayat I Huruf I UUD 45."'

Penolakan terhadap hukuman mati juga dilontarkan oleh Menteri Kehakiman Malaysia. Nazri Aziz yang dikutip oleh Ketua Dewan Pendiri Imparsial, The Indonesian Human Right Monitor, Todung Mulya Lubis dalam harian KOMPAS:

"Mentri Kehakiman dari Malaysia yang berpandangan cerdas dan radikal, Nazri Aziz mendukung seruan penghapusan hukuman mati di negaranya....Alasannya, selain tak akan 
mengurangi angka kejahatan, Mentri Kehakiman juga mengatakan, tak seorang pun berhak mencabut kehidupan orang lain meski orang itu telah mencabut kehidupan orang lain."

Jadi, eksekusi mati adalah ancaman pidana yang bertentangan dengan UUD 1945 sebab, konstitusi menegaskan bahwa hak untuk hidup adalah hak asasi yang tidak dapat dikurangi dengan alasan apa pun. Artinya, seluruh produk hukum yang mencantumkan pelaksanaan hukuman mati harus diubah.

Oleh sebab itu, Fundamentalisme HAM jelas menolak hukuman mati. Mereka yang telah dijatuhi hukuman mati memang telah melakukan kejahatan, tetapi tidak perlu ada penambahan korban jiwa lagi dengan mengeksekusi si pelaku kejahatan. Apalagi, hak hidup dijamin dalam UUD 1945 yang menjadi sumber hukum tertinggi Indonesia.

Fundamentalisme HAM menolak eksekusi mati karena eksekusi mati pada hakikatnya ekuivalen dengan menghilangkan nyawa seseorang. Dengan demikian, eksekusi mati bertentangan dengan hak hidup seseorang. Oleh karena itu tidak ada tempat sedikit pun untuk melegalisasi eksekusi mati dalam tata hukum. Melegalisasi eksekusi mati berarti menghilangkan hak untuk hidup seorang terpidana kejahatan.

\section{Refleksi Kritis Teologis}

Hal pertama yang perlu dikemukakan mengenai Fundamentalisme HAM dalam perspektif teologis adalah bahwa HAM bersumber pada klaim Allah terhadap manusia, bukan sebagai klaim atas orang lain. Maksudnya, bahwa HAM bukanlah teori atau paham yang dirumuskan oleh manusia dalam sejarah, tetapi pemahaman tentang apa yang dikehendaki Allah kepada manusia pada waktu manusia diciptakan (siapa manusia itu, apa makna eksistensinya dan apa tujuan hidupnya dari perspektif Allah). ${ }^{3}$ Jhon Stoot merangkumkan jawaban dari tiga pertanyaan itu dalam tiga perkataan. yaitu martabat, kesederajatan dan tanggung jawab (Kejadian 1: 26-28). ${ }^{4}$

Martabat manusia mencakup hubungannya dengan Allah sebagai gambar Allah. Sebagai gambar Allah. maka setiap manusia mempunyai hak dan kewajiban asasi yang sama, tidak ada yang lebih dan tidak ada yang kurang, semuanya sederajat. Kesederajatan ini mengimplikasikan hak setiap manusia untuk mewujudkan kemanusiaannya secara penuh sesuai dengan martabatnya sebagai gambar Allah yang bertanggung jawab penuh terhadap dirinya sendiri, terhadap hubungannya dengan sesama, terhadap seluruh alam ciptaan dan tanggung jawab penuh untuk membangun masa depan yang terbaik bagi generasi yang akan datang.

Jadi, klaim Allah dalam hal ini adalah akar kehidupan manusia. Manusia tidak berhak mencabut nyawa sesamanya. Hal ini tidak berarti tidak ada kejahatan, termasuk kejahatan yang menghılangkan nyawa manusia, tetapi jawaban atas terjadinya kejahatan tersebut harus dicari pada akar kehidupan manusia.

Hal kedua adalah, bahwa jika HAM dipahami hanya sebagai kalim atas orang lain dan tidak sebagai klaim Allah, maka fundamentalisme HAM (perjuangan HAM) tidak lebih dari sebuah ajang pergulatan kekuasaan dan rekayasa politik para penguasa. Kenyataan ini ada dalam kasus tiga nrany terpidana mati kerusuhan Poso yang meskipun tidak terbukti bersalah di pengadilan, namun tetap dijatuhi hukuman mati.

Sebagai warisan masa lalu, penerapan hukuman mati di Indonesia tidak lepas dari watak dan politik yang berperan saat itu. Sejak masa kolonial hingga kini, sejarah menunjukan bagaimana hukuman mati menjadi bagian manajemen politik kekerasan dan politik ketakutan Negara untuk mengontrol masyarakat....Disisi lain, penerapan hukuman mati terhadap ketiga orang itu menimbulkan kecurigaan, pertanyaan, dan bernuansa politis. Eksekusi mati kepada ketiganya akan memutus rantai dan jaringan yang terlibat kerusuhan Poso. ${ }^{5}$ 
Hal ini jelas menunjukan, bahwa rekayasa politik para penguasa telah menjadikan HAM sebagai klaim atas orang lain. Sebagai klaim dari pihak mayoritas yang mendiskreditkan sebuah komunitas minor.

Semua orang sudah tahu kenapa Almarhum saudara Tibo dkk harus secepatnya dieksekusi mati sebelum tuntas semua pemeriksaan 16 tersangka lainnya, karena untuk menutupi kesalahan Elite Politik....Hukum di Nusantara memang sudah bobrok sejak orde baru masuk....Eksekusi Tibo dkk mencerminkan politik mayoritas, padahal semua orang tahu Indonesia adalah Negara Kesatuan RI... dieksekusinya Tibo dkk menutupi masalah hukum yang bobrok. ${ }^{6}$

Hal ketiga adalah, bahwa prinsip hukum yang dipakai Allah menegakan HAM adalah "hukum itu dibuat untuk manusia dan bukan manusia untuk hukum" (Markus 2:27). Hukum itu ada untuk manusia dan hukum berkewajiban melindungi martabat manusia sebagai gambar Allah (hak hidup). Penggunaan hukum haruslah mengacu kepada Sang Pemilik dan Sumber segala hukum, yaitu Allah. Jadi, legitimasi terhadap hukum terletak pada apakah hukum itu dipakai untuk melindungi HAM atau tidak. Sebab, manusia baik sebagai individu maupun kolektif, memiliki gambar Allah dalam martabatnya (memiliki hak hidup).

Jika kasus tiga terpidana mati kerusuhan Poso disoroti secara teologis, maka dapat disimpulkan bahwa vonis mati dan eksekusi mati terhadap mereka adalah sebuah hasil rekayasa politik para penguasa yang mendukung kepentingan pihak mayoritas. Hal ini telah membuktikar bahwa hukum sudah tidak dipakai melindungi HAM dan sudah tidak mengacu pada Allah sebagai Sang Pemilik dan Sumber segala hukum. Karena hukuman mati bertentangan dengan prinsip hukum Allah, maka tidak ada alasan apa pun yang dapat digunakan untuk melegalkan eksekusi mati.

\section{Kesimpulan}

Masalah Hak Asasi Manusia banyak menyangkut atau berkenaan dengan aspek-aspek kehidupan manusia. Dengan demikian, dalam membahas Fundamentalisme Hak Asasi Manusia harus bertumpu pada konsep manusia yang tentunya tidak terlepas dari kodrat manusia itu sendiri, yakni ada bersama dengan sesamanya (eksistensi adalah koeksistensi). Eksistensi manusia yang koeksistensi hanya mungkin terwujud secara otentik apabila setiap manusia dapat bertingkah dengan tertib dan teratur. Ketertiban dan keteraturan ini pada hakikatnya merupakan perwujudan dari hukum. Dengan demikian, eksistensi manusia dapat terwujud secara otentik melalui hukum pula. Eksistensi manusia yang koeksistensi hanya akan terwujud apabila hukum itu sendiri dapat dikembalikan atau bersumber pada asas penghormatan dan pengakuan atas martabat manusia.

Oleh karena itu, adalah sebuah kewajiban bagi manusia untuk menolak dan melawan segala bentuk pelanggaran HAM, yaitu segala bentuk perlakuan (termasuk eksekusi mati) yang tidak memperlakukan manusia (baik secara individu maupun kelompok) sebagai gambar Allah dan yang menghalangi manusia untuk menghadirkan diri secara penuh dan otentik (dalam eksistensi yang koeksistensi) sesuai dengan martabatnya sebagai gambar Allah.

\section{Saran-Saran}

Tentang definisi dan rumusan tentang hak hidup manusia harus segera dapat dirumuskan secarayuridis dengan pasti, agar kepastian hukum dapat lebih terjamin. Undangundang yang mengatur masalah hukuman mati hendaknya ditinjau kembali dan disesuaikan dengan prinsip UUD 1945.

Masalah hak hidup manusia dan eksekusi mati adalah masalah yang sangat problematis dan dilematis. Banyak disiplin ilmu atau pihak yang harus terlibat di dalamnya. Diskusi, perdebatan dan tulisan-tulisan selanjutnya mengenai hukuman mati hendaknya mengkaji 
asumsi-asumsi yang mendasari hukuman mati dan efektivitasnya, serta menawarkan jalan keluar yang mampu menjaga harkat dan martabat manusia.

Orang Kristen hendaknya mengekspresikan tanggung jawab moralnya dengan turut memprotes keputusan pemerintah yang melegalkan eksekusi mati dalam tata hukum di Indonesia. Suara protes yang bertujuan meningkatkan kesadaran nasional serta membangun, walaupun dengan nada yang cukup pedas dan keras.

\section{Daftar Pustaka}

Abineo, J.L. Ch. Sekitar Etika dan Soal-Soal Etis. Jakarta: BPK, 1994.

Alkitab, Jakarta: Lembaga Alkitab Indonesia, 1998.

Kamus Besar Bahasa Indonesia Edisi Ketiga. Jakarta: Balai Pustaka, 2003.

$\mathrm{http} / /$ : id.wikipedia.org, Hukuman Mati.

http//: Jakarta.indymedia.org/newswire.

Karyadi, Petrus Yoyo. Euthanasia Dalam Perspektif Hak Asasi Manusia. Yogyakarta: Media Pressindo, 2001.

Mirriam, Budiarjo. Demokrasi di Indonesia. Jakarta: PT. Gramedia, 1994.

Penyunting: Sairin, Weinata dan J.M. Pattiasina. Hubungan Gereja dan Negara dan Hak Asasi Manusia: Bunga Rampai Pemikiran. Jakarta: BPK, 1994.

Setiabudi, Natan. Sikap dan Pemikiran Kritis Pdt. Natan Setia Budi Ketua Umum Persekutuan Gereja-Gereja di Indonesia (PGI) Menjelang dan Paska Pemilu 2004. Copyright @ 2004 Natan Setiabudi.

Sproul,R.C. Etika dan Sikap Orang Kristen. Malang: Gandum Mas, 1991.

Stoot, John. Isu-Isu Global Menantang Kepemimpinan Kristiani. Jakarta: Yayasan Komunikasi Bina Kasih/OMF,1994.

www.kompas.com, Eksekusi Mati di Poso Inkonstitusional (Jumat, 7 April 2006).

www.kompas.com, Hanya Doa yang Menguatkan Kami (Jumat, 7 April 2006).

www.kompas.com, Hukuman Mati Masih Diperlukan (Selasa, 11 Januari 2000).

www.kompas.com, Ketika Kematian Akan Dipaksakan Datang (22 Pebruarai 2003).

www.kompas.com, Tibo, Akbar, dan Muhaimin (Jumat, 7 April 2006).

(Footnotes)

'Kompas. Tibo: Hanya Doa yang Menguatkan Kami, (Jumat, 7 April 2006).

'Kamus Besar Bahasa Indonesia s.v "fundamentalisme"

"Ibid s.v "radikal"

"Ibid s.v "HAM"

${ }^{5}$ Jhon Stoot, Isu-isu Global Menantang Kepemimpinan Kristiani, (Jakarta: Yayasan Komunikasi Bina

Kasih/OMF, 1994), 199. Ide diambil dari Petrus Yoyo Kardi, Euthanasia Dalam Perspektif Hak Asasi

Manusia, (Yogyakarta: Media Pressindo, 2001), 120-130

${ }^{7}$ Kamus Besar Bahasa Indonesia s.v. "kodrat"

${ }^{8}$ Petrus Yoyo Kardi, Euthanasia Dalam Perspektif Hak Asasi Manusia, (Yogyakarta: Media Pressindo, 2001). 133.

${ }^{9}$ Kamus Besar Bahasa Indonesia s.v. "eksekusi",

${ }^{10}$ Ibid s.v. "mati"

" http/l: id.wikipedia.org, Hukuman Mati.

'www.kompas.com, Ketika Kematian Akan Dipaksakan Datang, (22 pebruari 2003).

${ }^{13}$ www.kompas.com.Hukuman Mati Masih Diperlukan, (Selasa. 11 Januari 2000).

1.t www.kompas.com, Eksekusi Mati di Poso Inkonstitusional, (Jumat, 7 April 2006).

${ }^{15}$ www.kompas.com. Tibo, Akbar, dan Muhaimin, (Jumat. 7 April 2006).

${ }^{3}$ Ide diambil dari Eka Darmaputera, Hubungan Gereja dan Negara dan Hak Asasi Manusia. (Jakarta: BPK, 1994), $71-72$.

+ Ide diambil dari Jhon Stoot, Isu-Isu Global Menantang Kepemimpinan Kristiani, (Jakarta: Yayasan Komunikasi Bina Kasih/OMF, 1994), 200.

www.kompas.com, Eksekusi Mati di Poso Inkonstitusional, (Jumat. 7 April 2006).

"http//: Jakarta. Indymedia.org/newswire. 